\title{
Оксана Краєва
}

ORCID iD 0000-0001-9681-9966

\begin{abstract}
кандидат психологічних наук, доцент кафедри практичної психології Інституту людини, Київський університет імені Бориса Грінченка, бул. І. Шамо, 18/2, 02154 Київ, Україна, o.kraieva@kubg.edu.ua
\end{abstract}

\section{КРИЗА ІДЕНТИЧНОСТІ ОСІБ ПІДЛІТКОВОГО ВІКУ В ПЕРІОД ТРАНСФОРМАЦІЙНОЇ НЕВИЗНАЧЕНОСТІ}

Узапропонованій статті поряд із здійсненням спроби теоретичного облрунтування аспектів прояву кризи ідентичності осіб підліткового віку, представлено результати емпіричного дослідження психологічних ознак кризи ідентичності та їі показників в період суспільної невизначеності. Емпіричні результати кризових аспектів ідентичності наведено за визначальним рівнем самоставлення підлітків та за рівнем суперечностей компонентного складу ідентичності осіб, втілених в їх «Я-образі» на етапі переживання кризи ідентичності. Наведено схему динаміки зміни ідентичності. Підкреслено, що криза ідентичності є втратою власне попередньо набутої форми дитячої ідентичності, за рахунок дезорієнтації підлітка та призведення до системних пошуків нових складових його "Я-образу», за умови узгодження їх із ідентифікаиійною матрицею особи.

Ключові слова: ідентичність; криза ідентичності; самоставлення; суперечності «Я-образу»; «Я»; «Я-реальне» - «Я-ідеальне».

Вступ. Сучасна суспільна криза національної ідентичності української держави, проявом якої $\epsilon$ етнічна, ідеологічна, мовна, конфесійна та політична розпорошеність, занепад духовних та національних чинників, розмивання системи цінностей (А.Ватерман, Е.Еріксон, Дж.Марсіа), негативно позначається на образі світу особистості, що стрімко дорослішає, ï ціннісних орієнтирах, переконаннях, ідентифікаційній матриці, соціальних ролях, які на кризовому етапі починають усвідомлюватися, виокремлюватися в єдиний ансамбль погоджених «Я-образів», втілюватись у власній неповторній ідентичності.

Період трансформаційної невизначеності на тлі соціально-економічної кризи суспільства безпосередньо негативно впливає на ще цілковито несформовану ідентичність індивіда, який опиняється в ситуації невизначеності, що заглиблює проходження етапу кризи ідентичності та нівелює деякі можливі надбання. Ця тенденція в більшості випадків призводить у підлітковому віці, до формування негативної ідентичності, дезінтеграції, відсутності життєвих планів, кризи майбутнього.
Оскільки криза ідентичності є важливим психологічним аспектом становлення особистості підлітка, перед сучасною психологічною наукою постає необхідність розробки чіткої системи розуміння показників кризи ідентичності підліткового віку, визначення ії компонентного складу та загальної ролі зазначеної кризи у розвитку особистості.

Метою статті $є$ дослідження особливостей прояву кризи ідентичності підлітків тринадцяти та чотирнадцяти років на етапі трансформаційної невизначеності.

У середині минулого століття Е. Еріксон $(1960 ; 1968)$ описав проблему, що виникає у дорослих як «кризу ідентичності» (вперше цей термін з'явився в науці у другій половині минулого століття та був запропонований у ході консультування під час війни для опису патологічного стану пацієнтів, які втратили почуття «Я», часовий континуум). Пізніше, криза ідентичності досліджується вченим в межах нормального розвитку особистості підліткового віку та наголошується, що підлітковий вік тісно пов'язаний із кризою ідентичності, вимагає індивідуальних та соціаль- 
но-особистісних виборів, ідентифікацій та самовизначень.

Як відомо науці, підлітковий вік $є$ періодом переживання особою «нормативної кризи», для якої характерні коливання сили «Я» та помітне посилення ролі конфліктів у взаємостосунках з оточуючими, зокрема дорослими.

Досліджувана нами криза ідентичності, завданням якої $є$ формування відчуття нової якісної форми ідентичності й уникнення небезпеки виникнення рольової, ідентифікаційної дифузності, немов би імплементується в межі підліткового періоду та представляє собою несумісності різних сторін «Я» особистості.

Окрім того, вона $є$ пов'язаною з несформованим почуттям ідентичності, вказує на наявність внутрішньо-особистісного конфлікту, який супроводжують гнітючі сумніви щодо себе, своїх дій, свого місця у групі (Еріксон, 1998).

Таким чином, криза ідентичності розгортається в підлітковому віці на тлі вікової кризи розвитку особистості підліткового віку (Краєва, 2016) та водночас постає життєвою кризою індивіда.

Наші погляди щодо стану кризи ідентичності подекуди вирізняються від концептуальних поглядів Е. Еріксона (1998), який у своїй концепції визначає кризу підліткового віку як кризу ідентичності, тобто формування ідентичності на тлі рольової невизначеності дитячого «Я». Ми ж у своїй роботі розмежовуємо обидві кризи: «підліткову кризу» та «кризу ідентичності в підлітковому віці» за психологічним сенсом, втіленням і наповненням (Краєва, 2016).

Криза ідентичності є втратою власне попередньо набутої цілісної форми (умовно назвемо ї̈ дитячою ідентичністю), яка дезорієнтує підлітка та призводить до системних пошуків нових складових «Я-концепції», за умови узгодження їх із ідентифікаційною матрицею особи.

Таким чином, криза ідентичності підліткового віку об'єктивно визначається як невідповідність компонентного складу попередньої дитячої ідентичності, контексту існування, що змінився, призводить особу до внутрішньо особистісного конфлікту.

Погоджуємося із думкою Е. Еріксона (1960; 1968), який вказує, що набуття ідентичності та володіння нею на кризовому етапі, означає: відчуття себе, свого буття як особи незмінним, незалежно від ситуації, ролі, самосприйняття; відчуття минулого, сьогодення та майбутнього, як єдиного цілого; відчуття зв’язку між власною безперервністю та визнанням цієї безперервності іншими людьми.

Запропоновані науковцями тенденції у поясненні кризи ідентичності, дозволили нам зосередити увагу на розумінні досліджуваного феномену кризи ідентичності підліткового віку в якості порушення ідентифікаційних процесів, внутрішньої цілісності, послідовності, тотожності, поведінкових стереотипів індивіда, у найширшому значенні як порушення ототожнення підлітка з власним «Я».

Наступне наукове питання, пов'язане із динамікою зміни ідентичності досліджуваного віку залишається допоки відкритим. Натепер ми можемо лише припустити, що процес динаміки зміни ідентичності може відбуватися за наступною схемою: (умовно) дитяча ідентичність $\rightarrow$ криза ідентичності, яка призводить індивіда до певної зміни ідентичності, набуття нової якісної форми ідентичності, а саме: невизначеної, наслідуваної, позитивної ідентичності, негативної або ж псевдоідентичності. Серед вказаних видів ідентичності, на нашу думку, лише позитивна ідентичність може призвести індивіда у майбутньому до осягнення та володіння зрілою ідентичністю. Особи з іншими вказаними формами (умовно) набутої ідентичності, з часом, схильні до переживання повторного факту кризи власної ідентичності.

Отже, досліджувана нами криза ідентичності підліткового віку (як іï ще називають: мораторій ідентичності (психосоціальний мораторій) або криза вибору), виражається в якості порушення, перш за усе, ідентифікаційних процесів, внутрішньої цілісності, послідовності, тотожності, поведінкових стереотипів індивіда, у найширшому значенні як порушення ототожнення підлітка $з$ власним «Я». Завдяки впливові кризи ідентичності підлітки відчувають, тією чи тією мірою, утруднення ідентифікаційного процесу, загострення суперечностей між «Я-реальним» та «Я-ідеальним», непогодженість особистісного і соціального аспектів «Я-концепції», дисбаланс часової перспективи «минуле - сьогодення - майбутнє», конфлікт конструктивної та деструктивної рефлексії.

Таким чином, криза ідентичності підліткового віку відображає: складний етап зміни, становлення та набуття якісно нової форми ідентичності; суперечливий, важливий процес, 
який вимагає від особи переосмислення набутих переконань, цілей, цінностей та ролей.

Емпіричний матеріал дослідження. Емпіричне дослідження показників прояву кризи ідентичності здійснювалося нами в двох репрезентативних підліткових групах (тринадцятирічні та чотирнадцятирічні підлітки) за допомогою наступного психодіагностичного інструментарію: методики «Автопортрет», розробленої Р. Бернсом та інтерпретованої О. Романовою та О. Потьомкіною (Романова, 1991), спрямованої для вивчення суперечностей «Я-образу» (між «Я-реальним» та «Я-ідеальним»), та методики «Вивчення Я-концепції в модифікації А. Прихожан (підлітковий варіант)» (2007), з метою виявлення ставлення до власного «Я», пов’язаного з проявами кризи ідентичності в підлітковому віці.

За обраними методиками, до сфери нашого інтересу, в контексті дослідження психологічних особливостей прояву кризи ідентичності підліткового віку, увійшли: загальний рівень самоставлення на етапі кризи (дуже високий, високий, середній, низький, занадто високий (група ризику)) та суперечності складових «Я-концепції».

Отримані емпіричним шляхом результати дослідження за методикою «Автопортрет» (табл. 1) дозволили нам визначитися 3 параметрами суперечностей «Я-образу» (між «Я-реальним» та «Я-ідеальним») на етапі кризи ідентичності.
3 результатів вивчення суперечностей «Я-образу» (між «Я-реальним» та «Я-ідеальним») підлітків, які наведені в табл. 1, зображення 56\% тринадцятилітніх відрізняється значними суперечностями між «Я-реальним» та «Я-ідеальним» у порівнянні 3 44\% чотирнадцятилітніх. Значні суперечності вказують на психологічну напругу та дискомфорт у структурі особистості на момент визначення з власним «Я» на етапі переживання кризи ідентичності.

Незначні суперечності між «Я-реальним» та «Я-ідеальним», виявлені нами у $36,5 \%$ підлітків обох груп, характеризують індивідів, які значно краще усвідомлюють власний «Я-образ», його незначні суперечності, прагнуть призвести своє «Я-реальне» до його «Я-ідеального» зразку.

Значущі статистично достовірні дані за відсутністю суперечностей «Я-образу», розцінені нами в якості показника кризи ідентичності, 3 віком підвищуються і досягають у чотирнадцятилітніх - $19 \%{ }^{*}$, на противагу $8 \%{ }^{*}$ у тринадцятилітніх $(\mathrm{p} \leq 0,05)$. Підвищення цього показника свідчить про неузгодженість модальностей між «Я-реальним» та «Я-ідеальним» значною мірою саме у підлітків чотирнадцяти років та вказує на складний перебіг кризи, коли особа плутається з визначенням «Я-образу» в межах згаданих категорій.

\section{Суперечності «Я-образу» (між «Я-реальним» та «Я-ідеальним»)}

Таблиця 1

\begin{tabular}{|c|c|c|c|c|c|}
\hline \multirow{3}{*}{$\begin{array}{l}\text { Параметри } \\
\text { суперечностей }\end{array}$} & \multicolumn{4}{|c|}{ Суперечності «Я-образу» } & \multirow{3}{*}{$\varphi_{\mathrm{eмп}}^{*}$} \\
\hline & \multicolumn{2}{|c|}{7 класи } & \multicolumn{2}{|c|}{8 класи } & \\
\hline & Абс. & $\%$ & Абс. & $\%$ & \\
\hline $\begin{array}{l}\text { значні } \\
\text { суперечності }\end{array}$ & 39 & 56 & 33 & 44 & 1.331 \\
\hline $\begin{array}{l}\text { незначні } \\
\text { суперечності }\end{array}$ & 25 & 36 & 27 & 37 & 0.096 \\
\hline $\begin{array}{l}\text { відсутність } \\
\text { суперечностей }\end{array}$ & $6^{*}$ & $8^{\star}$ & $14^{*}$ & $19^{*}$ & 1.829 \\
\hline Всього & 70 & 100 & 74 & 100 & \\
\hline
\end{tabular}

Примітка: $\varphi_{\text {емп }}^{*}>\varphi_{\text {крит }}^{*}(\mathrm{p} \leq 0,05) \varphi_{\text {крит }}^{*}=\{1,64(\mathrm{p} \leq 0,05), 2,31(\mathrm{p} \leq 0,01)$ 
За теоретичним узагальненням, неузгодженість «Я-образу» підлітка, його «Я-реального» 3 «Я-ідеальним», виступає одним із показником компонентного складу моделі кризи ідентичності підліткового віку, і за застосованою методикою, проявляється як у показниках значності суперечностей, так й у відсутності розбіжностей у зображеннях респондентів вказаних модальностей.

Отже, з результатів дослідження, виявлене підвищення $\left(19 \%{ }^{*}\right)$ неузгодженості модальностей «Я-образу» підлітків чотирнадцяти років, свідчить про переживання напруги, пов'язаної з проблемою пошуку власного «Я» на етапі кризи $(\mathrm{p} \leq 0,05)$ ідентичності.

Наступною було застосовано методику «Вивчення Я-концепції в модифікації А. Прихожан (підлітковий варіант)» (2007) з метою виявлення прояву самоставлення підлітків досліджуваних груп на етапі перебігу кризи ідентичності, пов'язаного із рівнем розвитку «Я-концепції (рис. 1).

3 аналізу отриманих результатів, дуже високий рівень, низький та «група ризику» за рівнем самоставлення в підлітковому віці, можуть виступати наступними показниками досліджуваної нами кризи ідентичності. Хоча й значущої статистичної різниці у виокремлених показниках кризи ідентичності підлітків тринадцяти та чотирнадцяти років нами не виявлено. Емпірична обробка показала, що підліткам зазначеної вікової категорії на період кризи ідентичності притаманний дуже високий (27\% семикласників та $33 \%$ восьмикласників) $\left(\varphi_{\text {емп }}=0.651\right.$, $\varphi_{\text {емп }}<\varphi_{\text {крит }}(\mathrm{p} \leq 0,05)$ рівень самоставлення, що свідчить про неадекватні тенденції у ставленні до власного «Я-образу», за рахунок нереалістичної оцінки себе на етапі кризи ідентичності.

Високий рівень самоставлення, притаманний $36 \%$ та $43 \%\left(\varphi_{\text {емп }}=0.87, \varphi_{\text {емп }}<\varphi_{\text {крит }}(\mathrm{p} \leq 0,05)\right.$ досліджуваних, вказує на відповідність соціальному нормативу. 3 результатів вбачаємо, що до чотирнадцяти років майже у $43 \%$ підлітків нормалізується рівень самоставлення стосовно відповідності соціальному нормативу, за умови розширення в компонентному складі ідентичності особи самоідентифікацій, пов'язаних із визначенням власного «Я» у соціальному контексті.

Середній рівень самоставлення було виявлено у $29 \%$ підлітків тринадцяти років та $24 \%$ чотирнадцяти $\left(\varphi_{\text {емп }}=0.63, \varphi_{\text {емп }}<\varphi_{\text {крит }}(\mathrm{p} \leq 0,05)\right.$. За низьким рівнем самоставлення та «групою ризику» виокремлено в цілому $8 \%$ підлітків тринадцяти років на противагу підліткам чотирнадцяти, яких за окресленими параметрами не виявлено жодного. Емпіричні дані 3 визначення рівня самоставлення підлітків 13-14 років на етапі кризи ідентичності представлені на рис. 1.

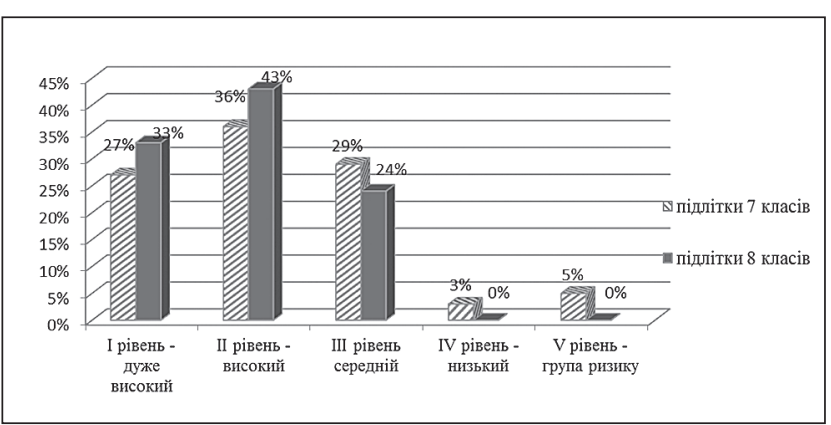

Рис. 1. Зведені порівняльні дані результатів двох груп з визначення рівня самоставлення підлітків на етапі розгортання та перебігу кризи ідентичності

Таким чином, за рівнем самоставлення на етапі кризи ідентичності, підлітки тринадцяти років поступаються підліткам чотирнадцяти, рівень самоставлення яких підвищується з віком, але не набуває статистично достовірно значущих відмінностей.

Саме тому вважаємо за необхідне наведення зведених емпіричних даних з визначення загального рівня самоставлення підлітків двох досліджуваних груп (рис. 2).

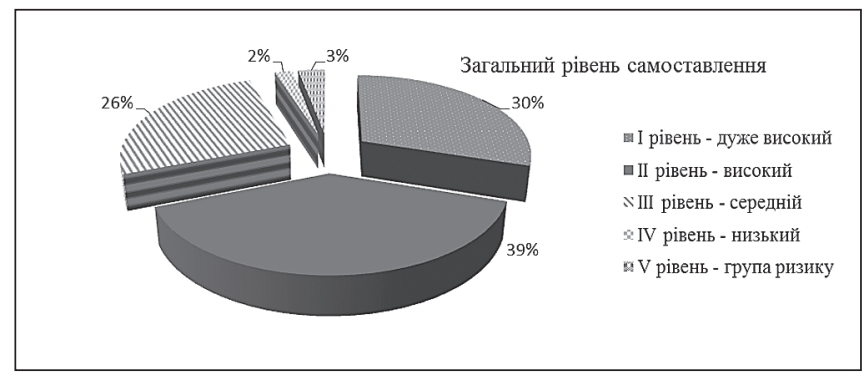

Рис. 2. Зведені загальні дані результатів з визначення рівня самоставлення підлітків на етапі розгортання та перебігу кризи ідентичності

3 результатів емпіричного дослідження можна зазначити, що сукупність осіб підліткового віку з дуже високим рівнем (30\%), низьким (2\%) та рівнем «групи ризику» $(3 \%)$ за категорією самоставлення, відчувають на досліджуваному віковому етапі перебігу кризи ідентичності, психологічний дискомфорт, пов'язаний з усвідомленням сторін власного «Я-образу», втіленому в «Я-концепції». 
Підсумовуючи отримані емпіричним шляхом результати дослідження стану показників перебігу та прояву кризи ідентичності представників досліджуваних груп, виокремлено основні тенденції трансформації ідентичності підлітків тринадцяти та чотирнадцяти років окремо.

Висновки та перспективи подальших досліджень. Виходячи з описаних емпіричних результатів, можемо сформулювати наступні узагальнення.

Аналіз емпіричного дослідження стану проблеми кризи ідентичності підліткового віку, дозволив стверджувати, що під поняттям криза ідентичності розуміємо: період конфлікту між елементами компонентного складу ідентичності, що розгортається довкола переходу від форми дитячої ідентичності до набуття та осягнення придбаної якісно нової іï форми; зміна ідентифікаційної матриці, що призводить до утруднення та порушення ідентифікацій індивіда; загострення суперечностей між «Я-реальним» та «Я-ідеальним».

Отримані результати дозволили виявити певні відмінності в структурі ідентичності підлітків тринадцяти та чотирнадцяти років на етапі кризи ідентичності, що стосуються суперечностей «Я-образу» - між «Я-реальним» та «Я-ідеальним» (значимість і відсутність розбіжностей між «Я-реальним» та «Я-ідеальним»).

Перспективу подальших наукових розвідок вбачаємо в дослідженні комплементарно-кризового складу ідентичності особистості в період трансформаційної невизначеності суспільства.

\section{Література}

Краєва О. А. Проблема кризи ідентичності в період нормативної кризи підліткового віку. Педагогічний процес: теорія і практика. 2016. Вип. 1. С. 46-50.

Прихожан А. М. Диагностика личностного развития детей подросткового возраста. Москва: АНО «ПЭБ», 2007. 56 c.

Романова Е. С., Потемкина О. Ф. Графические методы психологической диагностики. Москва: Дидакт, 1991. 164 с.

Яблонська Т. Теоретико-методологічні основи дослідження розвитку ідентичності дитини в системі сімейних взаємин. Психологія особистості. 2015. № 1 (6). С. 250-260. doi: 10.15330/ ps.6.1.250-260.

Erikson E. H. Identity, Youth, and Crisis. New York: W. W. Norton and Co., 1968. P. 226-341.

Ericson E. H. The problem of ego identity. Stein M. R. at al. (Eds.) Identity and anxiety: Survival of the person in masssociety. Glencoe: The Free Press, 1960. P. 116-154.

\section{References:}

Krajeva, O. A. (2016). Problema kryzy identychnosti v period normatyvnoji kryzy pidlitkovogho viku. [Problem of identity crisis during crisis normative adolescence]. Pedaghoghichnyj proces: teorija $i$ praktyka, 1, 46-50 (ukr).

Prihozhan, A. M. (2007). Diagnostika lichnostnogo razvitija detej podrostkovogo vozrasta [Diagnosis of personal development of adolescents]. Moskow, Russia: $\mathrm{ANO}$ «PJeB» (rus).

Romanova, E. S., \& Potemkina, O. F. (1991). Graficheskie metody psihologicheskoj diagnostiki [Graphic methods of psychological diagnosis]. Moskow, Russia: Didakt (rus).

Jablonsjka, T. (2015). Teoretyko-metodologhichni osnovy doslidzhennja rozvytku identychnosti dytyny v systemi simejnykh vzajemyn [Theoretical and methodological foundations of the study of the development of the identity of the child in the system of family relationships]. Psykhologhija osobystosti, 1 (6), 250-260. doi: 10.15330/ps.6.1.250-260 (ukr).

Ericson, E. H. (1968). Identity, Youth, and Crisis. New York, USA: W. W. Norton and Co., 226-341 (eng). Ericson, E. H. (1960). The problem of ego identity. In Stein M. R. at al. (Eds.), Identity and anxiety: Survival of the person in mass society (pp. 116-154). Glencoe, USA: The Free Press (eng). 


\title{
КРИЗИС ИДЕНТИЧНОСТИ ПОДРОСТКОВ В ПЕРИОД ТРАНСФОРМАЦИОННОЙ НЕОПРЕДЕЛЕННОСТИ
}

Краевая Оксана, кандидат психологических наук, доцент кафедры практической психологии Института человека, Киевский университет имени Бориса Гринченко, бул. И. Шамо, 18/2, 02154 Киев, Украина, o.kraieva@kubg.edu.ua

В статье наряду с осуществлением попытки теоретического обоснования аспектов проявления кризиса идентичности подростков, представлены результаты эмпирического исследования психологических характеристик кризиса идентичности и проявления ее показателей в период общественной неопределенности. Эмпирические результаты кризисных аспектов идентичности приведены с учетом определенного уровня самоотношения субъектов, наряду с уровнем противоречий компонентов идентичности, воплощенных в «Я-образе» подростка на этапе переживания кризиса идентичности.

Приведена схема динамики изменения идентичности. Подчеркнуто, что кризис идентичности является собственно потерей предварительно приобретенной формы детской идентичности, за счет дезориентации подростка, приведения его к системным поискам новых составляющих «Я-образа», при условии согласования их с идентификаиионной матрицей.

Ключевые слова: идентичность; кризис идентичности; самоотночение; противоречия «Я-образа»; «Я»; «Я-реальное»- «Я-идеальное».

\section{CRISIS OF IDENTITY OF PERSONS OF TEENAGE AGE IN THE PERIOD OF TRANSFORMATIONAL UNCERTAINTY}

\author{
Kraieva Oksana, PhD (Psychology), Associate Professor of Department of Practical Psychology, \\ Institute of Human Sciences, Borys Grinchenko Kyiv University, \\ 18/2 Blvd. I. Shamo, 02154 Kyiv, Ukraine, o.kraieva@kubg.edu.ua
}

In the offered article near implementation of attempt of theoretical justification of aspects of manifestation of crisis of identity of persons of teenage age, results of an empirical research of psychological signs of crisis of identity and its indicators in the period of public uncertainty are presented.

Definition of a concept crisis of identity is considered as the conflict between elements of component structure of identity that at a stage of crisis of identity is developed around transition from a form of children's identity to acquisition and understanding of the acquired her qualitatively new form. The research of psychological signs and features of manifestation of crisis of identity of teenage age is chosen the purpose of article.

Empirical results of crisis aspects of identity are given behind the defining level self-relations teenagers and behind the level of contradictions of component structure of identity of the faces embodied in them "Self-Concept» at a stage of experience of crisis of identity. The scheme of dynamics of change of identity is provided. It is emphasized that crisis of identity is loss of actually previously acquired form of children's identity, at the expense of a disorientation of the teenager and reduction to system search of new components to his "Self-image», on condition of their coordination with an identification matrix of the person.

It is claimed that crisis of identity understands as a concept: first of all, change of an identification matrix which leads to difficulty and violation of identifications of the individual; aggravation of contradictions between "Real-Self» and «ldeal-Self».

As a result of a research the main differences in structure of identity of teenagers of thirteen and fourteen years at a stage of crisis of identity are revealed and indicators of crisis of identity of teenagers of the studied groups are allocated.

Key words: contradictions «Self-Image»; "Ideal-Self»; identity; identity crisis; "Real-Self»; Self-relations; «Self». 